\title{
The softwood lumber dispute: Is a solution possible?
}

\author{
by Francis Barriault' ${ }^{1}$, François Bellavance ${ }^{1}$, Julien Dutil-Seguin ${ }^{1}$, Catherine Gagné1, \\ Alexandre Gendron ${ }^{1}$, Pierre-Louis Harton ${ }^{1}$, Vincent Robillard-Cogliastro ${ }^{1}$ and Stephen Wyatt?
}

\begin{abstract}
Canadian exports of softwood lumber to the USA have long been a source of conflict. As the last Softwood Lumber Agreement expired, we examined this issue as a University class project in forest policy. This text presents our analysis of the history of this conflict and the positions of various actors, along with our twenty-year plan for resolving this conflict. Our strategy is in three phases, corresponding to our expectations of future events: five years of conflict and negotiation that we should use to prepare certain changes in our forest sector; ten years under a new agreement during which we can implement these changes; followed by another conflict that we hope Canada will win, resulting in lumber becoming just another traded commodity. Our policy has four key elements: a gradual transition to market-price systems for 55\% of public forest lumber volume; an expansion of value-added transformation and diversification of products; a reduction of softwood lumber production; and, a coordination role for the Canadian Council of Forest Ministers. We do not believe that our proposition is perfect, but we consider that it offers an option for breaking out of the box that characterises this conflict.
\end{abstract}

Keywords: softwood lumber, US-Canada relations, Forest policy, International timber trade

\section{RÉSUMÉ}

L'exportation du bois d'œuvre canadien aux États-Unis est depuis longtemps une source de conflit. Avec l'expiration de l'entente sur le bois d’œuvre résineux, nous avons examiné cet enjeu pour un projet dans un cours universitaire de politique forestière. Ce texte présente notre analyse de l'historique de cet enjeu et les acteurs engagés, ainsi que notre plan de vingt ans pour résoudre ce conflit. Notre stratégie comporte trois phases, en fonction de ce que lavenir laisse présager : cinq ans de conflit et de négociation que le Canada devrait utiliser pour préparer certains changements dans notre secteur forestier; dix ans avec une nouvelle entente qui nous permettra de mettre en ouvre ces changements; et finalement, un autre conflit que, espérons-le, le Canada gagnera afin que le bois d’ouvre devienne simplement une autre commodité dans nos échanges commerciaux. Notre politique a quatre volets : une transition graduelle vers un système de marché pour la vente de $55 \%$ de volumes provenant des forêts publiques; le renforcement de la valeur ajoutée et la diversification de nos produits; une réduction dans le volume de bois d’ouvre résineux produit; et un rôle de coordination pour le Conseil canadien de ministres de forêts. Nous ne croyons pas que notre proposition est parfaite, mais nous pensons quelle offre une option pour sortir du carcan dont ce conflit semble se trouver.

Mots clés : bois d'oeuvre résineux, relations canado-américaines, politique forestière, commerce international du bois

\section{Introduction}

We are writing this Introduction on October $12^{\text {th }}$ 2016. At midnight tonight, the one-year grace period established by the 2006-2015 Softwood Lumber Agreement expires and Canada and the USA are once again heading for a forest sector trade war. Last year, as forestry undergraduate students, we analysed the long history of this dispute, the positions of the various parties and we sought to understand what was likely to happen. Despite the optimistic statements of Prime Minister Justin Trudeau and President Barack Obama in March 2016, the issue has not been resolved. Are Canada and the USA doomed to repeat this scenario or is it possible to imagine another solution?

In autumn 2015, as part of a Forest Policy course at the Université de Moncton (New Brunswick), we chose to analyse the Softwood Lumber Agreement (SLA) as a current issue in forest policy. Clearly, this is an issue with an important impact on Canada's forest sector and on our future careers. Instead of using a classic rationalist model of Forest Policy (e.g., Ellefson 1992), we adopted a model based on the work of Mayers and Bass (1999). We began by examining the past history of this issue and proceeded to analyse how the issue was being debated and the interests and recommendations of the various actors. Subsequently we looked at the different options available and arrived at our own suggestions as to a possible way of moving forward. This is what we share with you in this article, but there are no quick fixes-our proposal has a twenty year time-frame.

\section{The History of the Dispute}

The "Lumber War" between Canada and the USA has a long history and has already involved military action. Access to

\footnotetext{
${ }^{1}$ Students, Université de Moncton, École de foresterie, Edmunston, New Brunswick

${ }^{2}$ Professor, Université de Moncton, École de foresterie, Edmunston, New Brunswick
} 
timber resources along the St. John River was one of the causes of the Aroostook War (1838-39), resulting in New Brunswick loosing parts of the province to northern Maine, USA. The early and mid-1900s also saw tariffs and complaints about Canadian lumber in the US market. The current cycle of alternating conflict and agreement began in 1982 (before most of us were born), when a group of US timber companies complained that Canada was unfairly subsidising timber production. Examining this complaint, the US International Trade Administration (ITA) concluded that there was no proof of subsidies-defined as being a benefit offered to a specific business or group of businesses (Cashore 1997, Zhang 2007). The next round, Lumber II, began in 1986, and this time the ITA concluded that links between the paper and sawn-timber sectors in certain provinces effectively caused a subsidy. Negotiations between the two countries resulted in an agreement and to Canada imposing a $15 \%$ duty on sawn timber exports to the USA. In 1991, Canada decided that data on royalties in Canada indicated that the situation had changed and unilaterally withdrew from this agreement, launching Lumber III. The US responded rapidly, with the ITA imposing an interim duty of $14.48 \%$ in March 1992 before adjusting this to $6.51 \%$ in May 1992 and again to $11.54 \%$ in December 1993. Arbitration efforts by a joint USCanada panel failed, US producers filed legal action and Canada referred the dispute to international arbitration. At the same time, negotiations around the North American Free Trade Agreement (NAFTA) were seen as a priority, with lumber finally being excluded from NAFTA so that the bigger deal could be ratified. Following ratification of NAFTA and decisions by international tribunals, the US Department of Commerce reversed its earlier positions and revoked the duties. Consultations on a new agreement began in December 1994, notably including the refund of a significant part of $\$ 500$ million in duties collected by the US Government.

The Softwood Lumber Agreement (SLA-1) signed in April 1996 ended Lumber III and established the terms for five years of relative calm (although there were several minor battles). Under this Agreement Canadian producers agreed to limit their exports by accepting a quota system, with additional duties being imposed for exports in excess of this quota. The Maritime Provinces were excluded from these quotas and duties and enjoyed unfettered access to the US market. When the SLA expired on $31^{\text {st }}$ March 2001, US timber producers immediately lodged another complaint with the ITA, marking the beginning of Lumber IV. Again, the response was fairly rapid, with the US government imposing an interim duty of $19.3 \%$ in August 2001 and a permanent duty of $27.2 \%$ in May 2002. However, between April and August 2001, Canadian producers did enjoy unlimited access to US timber buyers. Negotiations and a draft deal in March 2003 failed, being followed by NAFTA and World Trade Organisation (WTO) rulings that were considered a victory for Canada (Gagné and Paulin 2013). A US appeal was refused by the WTO in December 2005, leading the USA to reduce duties to $10.8 \%$. A subsequent NAFTA decision in March 2006 also supported the Canadian position. However, by this time Canadian timber producers had been suffering several years of high duties, a forest sector crisis, and a global economic crisis, leading to mill closures and job losses. In the federal election of January 2006, the Conservatives under Stephen Harper gained power and promised to negotiate a new timber deal with the USA. Agreed to in late April and coming into effect on October $12^{\text {th }}$ 2006, a new Softwood Lumber Agreement (SLA-2) again imposed constraints on Canadian exports, notably duties if US prices fell below $\$ 355$ per thousand board feet on the Random Lengths Framing Lumber Composite (FLC) price-a widely used market indicator. Again, the Maritime Provinces were exempt. Importantly, the US agreed to return approximately $\$ 4$ billion in duties collected since 2001, although it kept back $\$ 1$ billion. This time the Agreement was signed for a period of sevenyears and was extended for two years, taking us through to October $12^{\text {th }} 2015$.

In comparison to previous conflicts, Lumber $\mathrm{V}$ began more quietly. Canadian proposals to renew or extend SLA-2, made before it expired, were refused by the USA, signalling that US producers felt that a change was needed. SLA-2 also created a "cooling off" period of twelve months during which no new complaints would be lodged. News media reported that the governments were discussing the issue and Prime Minister Trudeau and President Obama stated on March $10^{\text {th }}$ 2016 that they hoped to resolve the dispute within 100 days. Nevertheless, the twelve-month period of grace expired on October $12^{\text {th }} 2016$ without an agreement, and US producers lodged a formal complaint on November $25^{\text {th }} 2016$. Lumber $\mathrm{V}$ is now underway.

Fig. 1 summarises movements in volumes and prices for softwood exports from Canada to the US over the last twenty years. Fig. 1a shows monthly export volumes oscillating around $1400 \mathrm{Mbf}$ (million board feet) through the 1990s, increasing during the US housing boom up to 2006, slumping to under $750 \mathrm{Mbf}$ for all of 2009, and finally climbing above $1000 \mathrm{Mbf}$ for most of 2014. The expiry of SLA-1 in March 2001 coincided with a peak in exports over $2000 \mathrm{Mbf}$ the following month, and again in May 2002. However, any stabilising effect of SLA-2 in 2006 appears to be overshadowed by falling demand and prices with the end of the US housing boom and the subsequent economic crisis. Market prices are shown in Fig. 1b, using both the Random Lengths FLC in US dollars and the Pribec index, calculated in Canadian dollars by the Quebec Forest Industry Council (QFIC). The FLC stayed generally above the \$ 355 threshold while SLA-1 was in force, was generally below in 2000 and in the early years of Lumber IV, before climbing again with the housing boom. The housing slump drove prices to record lows (\$ 195 in March 2009); however gains from 2009 to 2014 were slow and irregular, with 2015 prices dropping below the threshold despite steadily increasing export volumes. The difference between the FLC and the Pribec index highlights the effect of the Canadian dollar; a weak dollar of the early 2000s provided some protection from the low FLC, while a stronger one unfortunately coincided with the economic crisis. Finally, Fig. 1c shows Canadian softwood exports as a proportion of combined US production and Canadian exports (quarterly rather than monthly values) - providing an indication of the relative position of US and Canadian producers within the US market. During SLA-1, this ratio hovered around 33\%, before increasing slightly during Lumber $\mathrm{V}$ and then falling with the housing slump, attaining a low of $24 \%$ in 2011 . While the 


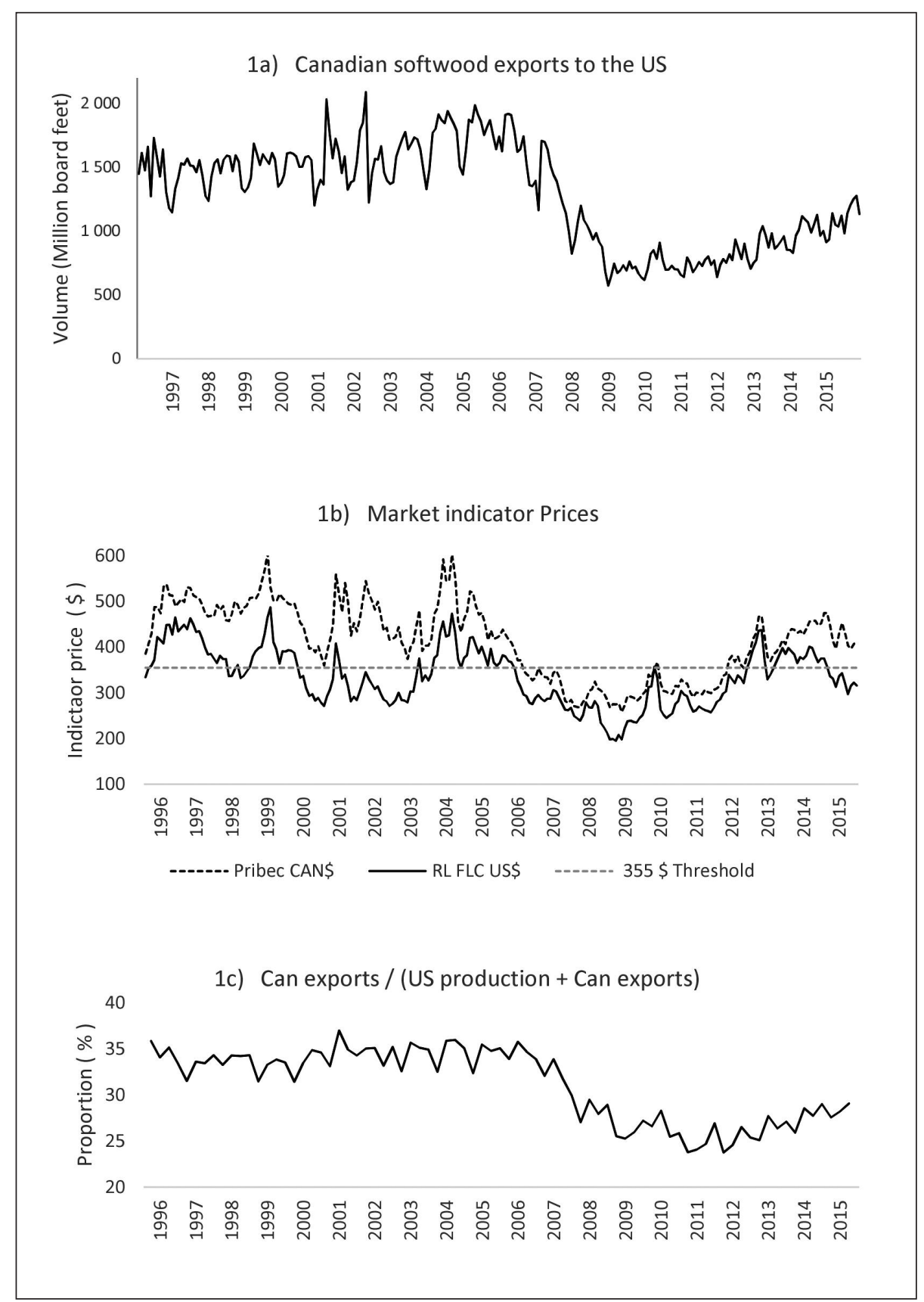

Fig. 1. Key indicators for Canadian softwood exports to the USA 1996-2015. 1a) Monthly volume of Canadian softwood lumber exports to USA. Source QFIC, Statistics Canada. 1 b] Monthly average market indicator prices: Random Lengths Framing Lumber Composite(USD) and Pribec (CAD). Source: Random Lengths, QFIC. 1 c) Quarterly ratio of Canadian softwood lumber exports divided by (US softwood lumber production plus Canadian softwood lumber exports to US]. Source: QFIC.

ratio is again increasing, the rate of increase is still slower than that of the volume of exports-Canadian exporters are not recapturing the market share that they lost between 2006 and 2011.

Summarising a long and complex history is always risky. However, it is worth noting that US arguments that Canadian timber benefits from major subsidies have been largely rejected by international trade tribunals (although there are important nuances in these decisions). Furthermore, the deals that are negotiated to end each dispute usually involve measures to increase prices in the US timber market while limiting the quantity of Canadian timber available in this market. Parajuli and Zhang (2016) examined the effects of SLA- 2 on the US timber market, concluding that it reduced imports from Canada by $7.78 \%$ during those months when export duties applied, that US lumber producers gained $\$ 1.6$ billion while consumers lost $\$ 2.3$ billion during the term of the Agreement. It appears this conflict is more about price and market share than whether or not Canadian governments subsidise timber production.

\section{The Actors Engaged in the Dispute}

The second step of our analysis was to understand who was involved in this dispute, why they were adopting certain positions and what options they were proposing for the future. We quickly realised that this does not split simply along USA-Canada lines.

Timber producers are an appropriate starting point. On the US side, the US Lumber Coalition (USLC, previously the Coalition for Fair Lumber Imports) has its origins in 1982, and has had a key role in both petitioning the administrative branches of the US government and in lobbying elected officials (Zhang and Laband 2005) ${ }^{3}$. In 2006, Coalition members received $\$ 500$ million as their share of the $\$ 1$ billion retained by the USA in accordance with the SLA-2. Interestingly, the USLC appears to have remained active through the "pause" between 2006 and 2016, identifying problems with the implementation of SLA-2. For their part, Canadian timber producers are highly dependent on the US mar-

${ }^{3}$ The lobbying review site, OpenSecrets, documents reported lobbying expenditures of $\$ 6.1$ million by the USLC from 2000 to 2006 in comparison to an average of about $\$ 80000$ per year from 2010 to 2016. http://www.opensecrets.org/lobby/clientsum.php?id= D000049396 
ket (over $60 \%$ of Canadian production in 2005 but $50 \%$ in 2014), while also denying the allegation that they are subsidised by Canadian governments. While the USLC provides a united voice, Canadian lumber producers are mainly represented by provincial associations, reflecting differences in the industry and the forests across the country. It appears likely that this has hampered the Canadian response to the USLC.

Governments on each side are being expected to act both as advocates and referees. The disputes typically begin with a petition by the USLC to the International Trade Commission (an agency of the US Department of Commerce) that decides if the complaint is justified and recommends appropriate duties. Discussions between trade negotiators from both governments usually follow, with each side also consulting with timber industry associations. While both sides argue in favour of "free trade", there are clearly differences in applying the term, and both governments are under pressure to maintain domestic industry and employment. These issues were highlighted during the 2005-2006 Canadian elections when the dispute became an election issue (albeit minor) with the Harper-led opposition criticising the lack of effort by the Martin-led government to resolve the dispute, which was causing mill closures and job losses across the country. Similarly, free trade rhetoric in the USA exists alongside strong protectionist positions, as demonstrated by both candidates in the 2016 Presidential campaign. In Canada, the situation is also complicated by differences in the ways that provincial governments manage public forests (and perceived subsidies) according to their own situation and priorities.

There are also other actors. Timber buyers in the USA, represented by American Consumers for Affordable Homes and by the National Association of Home Builders, should benefit from easier access to Canadian timber and are potential allies for Canadian producers. However, studies of the dispute suggest that these groups are less effective in lobbying the US government, noting that producers are concentrated in certain key states while consumers are widely distributed (Zhang and Laband 2005, Descôteaux and Martin 2009). In Canada, a number of environmental and indigenous groups have given explicit or tacit support to US producers, affirming that forest management practices were not appropriate or sustainable on environmental or social grounds. However, the Grand Council of Crees in Quebec also noted that free trade in lumber would encourage clear-cutting on their traditional lands. The lumber dispute is not just about subsidies, market share or prices, but also reflects concerns about environment, housing and indigenous rights among others.

Finally, international actors such as the World Trade Organisation and the administrative agencies of the General Agreement on Trade and Tariffs and the North American Free Trade Agreement are also involved. These agencies have a particular role as adjudicators in the dispute and while they are generally in favour of liberalising trade, their rulings adhere tightly to their own mandates and definitions. Canadian producers have been broadly successful in these adjudications, but predicting future decisions is risky.

\section{The Heart of the Dispute}

Although the USLC continues to maintain that Canadian timber producers benefit from government subsidies and advantages, rulings by the international tribunals have gener- ally countered this position and we do not believe that this is the real issue. As Zhang (2007: 271) concludes “.. notwithstanding rhetoric from the Coalition for Fair Lumber Imports about "market-based" changes to provincial stumpage, the lumber dispute is all about limiting Canada's market share and raising prices in the U.S. market." The last two SLAs increased costs for Canadian producers and limited the supply of Canadian timber, thereby supporting timber prices in US markets. SLA-1 was followed by several years of high prices, but SLA-2 coincided with the US housing slump and the economic crisis which drove down prices for all producers. Higher market prices are, of course, a significant benefit for US producers. They are also beneficial for Canadian producers when duties are not being applied. It also appears likely that the recurring conflict heightens uncertainty in the Canadian timber sector, reducing investment and productivity, which also reduces deliveries of Canadian timber to US markets. Finally, it is important to remember that the 2006 agreement resulted in \$ 500 million being distributed to USLC members - which could provide an additional incentive for launching Lumber V.

Although the heart of the dispute may be market prices, we cannot ignore the difference in forest management systems between the two countries. Private ownership accounts for only $8 \%$ of Canada's forests, but $57 \%$ of US forests (Siry et al. 2015), with large timber management organisations being particularly important in the US but generally absent in Canada. Private forest owners in the US may be expected to be more efficient in capturing rises in timber prices than in Canada, where governments adjust royalties more slowly. Zhang (2007) considers that Canada's rich endowment of natural forests does provide it with a competitive advantage and also notes that the strength of Canadian provinces means that our political institutions do not work well in trade disputes with the US. As Canadians, we are proud of our provincial public forest system and do not believe that our forests should be privatised or centralised. We note that several provinces are experimenting with alternative timber pricing and sales models, and we believe that this provides a partial answer to US complaints.

Some Canadian producers are calling for "free trade" in lumber with the US. While this is an attractive ideal, we also believe that it is unrealistic in the circumstances-just as unrealistic as expecting Canadian producers to agree with US complaints about subsidies. Another response is needed.

\section{Our Policy Response}

In seeking a realistic policy on the softwood lumber dispute, we must provide arguments that counter US perceptions of subsidies and that demonstrate their absence, while also promoting free access of Canadian lumber to the US market. Our policy must respect the importance that Canadians attach to publicly-owned forests and our values and perceptions related to multiple-use and to the environment. The policy also needs to recognise the constitutional roles of provincial and federal governments, the rights of Aboriginal peoples, the economic importance of the forest sector and diverse needs of manufacturers in the sector, and the increasing role and expectations of actors such as environmental groups. Accordingly, our policy response is oriented around several guiding principles:

- Maintaining public ownership of Canadian forests (con- 
sistent with Aboriginal rights), with management regimes that reflect the distinct characteristics of each province;

- Maintaining and expanding the forest sector's contribution to the Canadian economy;

- Recognising the importance of multiple-use of these forests for Canadians and allowing the full range of stakeholders to participate in their management;

- Expanding market-price mechanisms within provincial timber sales systems (such as auctions and private-forest benchmarking);

- Promoting value-added products, innovative fibre uses (such as nanocrystalline cellulose) and enhanced value for non-timber uses of forests (recreation, water, non-fibre products); and,

- Reducing the volume of softwood lumber exported to the US.

We do not expect all actors to agree on these principles and some are more difficult to achieve than others. Nevertheless, we consider that a suite of bold measures is the only way to break out of the cyclic nature of the softwood lumber dispute. We consider that this policy can be implemented through four key interventions:

\section{Reform timber sales systems to sell $55 \%$ of public volume through market-based mechanisms}

In recent years several provinces have made significant changes to their timber pricing systems, establishing armslength agencies that use auctions and other techniques to establish a fair market-price, including British Columbia, Manitoba and Quebec (Ziedi et al. 2014). In the past, the Maritimes were exempt from provisions of the SLA because of the extent of the private forest market in these provinces (but this may no longer hold after Lumber V). We propose that each province modify its timber sales system so that at least $55 \%$ of the volume from public forests is sold through market-based mechanisms. We do not propose a single approach, but rather consider that each province should develop its own system consistent with the needs of the province and their constitutional responsibilities. We recognise the challenges involved in modifying forestry regimes and propose an implementation period of 10 years, allowing increasing volumes of timber to be placed on an increasingly open market. Maintaining $45 \%$ of public volume under traditional systems will provide some stability for industry and flexibility for government in managing economic, social and policy objectives. Of course market-based systems are not a panacea and implementing these systems will certainly require adjustments and corrections. In particular, we note challenges related to avoiding collusion and cartels, improving efficiency, establishing floor and ceiling prices, and reconciling flexible pricing with long-term contracts (such as 25year management agreements).

\section{Expand value-added transformation, innovation and product diversification}

US complaints are directed at softwood lumber, which remains our most important forest sector export ( $\$ 8.3$ billion out of total forest exports of $\$ 30.8$ billion in 2014; RNCanada 2016). It is also a relatively low-priced commodity that is vulnerable to competition from other products, as well as US producers. We believe that optimising future value of our forests will depend upon expanding second and third transformation, developing new products and expanding and diversifying our value-creation chains. Transformed products are less vulnerable to US complaints about subsidies and enable Canadian businesses to create more jobs and greater economic activity with the same volume in comparison to exporting lumber. However, we also recognise that many reports and government initiatives over the last decade have sought to expand value-adding and innovation, but that achievements have not matched this rhetoric. Some provinces are adopting a more integrated approach of linking research and development, revisions in forestry regimes and pricing systems, and financial support for expanding value chains and developing new markets. We consider that financial resources, both private and governmental, would be more gainfully applied in promoting transformation of our forest sector than in seeking to maintain softwood lumber exports at any price.

\section{Reduce both softwood lumber production and overall harvesting levels}

The relative position of Canadian exports, as illustrated in Figure 1c) fluctuated between $32 \%$ and $37 \%$ prior to the housing slump, with SLA-1 keeping this below 35\%. The nature of the last two SLAs suggests that US producers recognise the need for Canadian lumber, but protest when the proportion rises or prices fall. In both 1996 and 2006 Canada accepted "voluntary" limits on the volume exported to the USA. If prices rise as a result of this restricted supply, both US and Canadian producers are likely to benefit. While it appears possible that higher profits on a reduced volume could offset lower profits on large volumes, economic modelling would be necessary to test this under various scenarios. Provincial actions to reduce lumber production by reducing harvesting allocations could provide a better return to industry, especially if some of this volume was transferred to innovative non-lumber production.

Furthermore, Canadian forests remain the site of conflicts over management and harvesting levels, with a broader range of stakeholders challenging the dominance of traditional forestry enterprises (sawmills and pulp-and-paper manufacturers). A familiar call from environmentalists, Aboriginal groups, and other stakeholders is to take account of other forest uses and values, giving rise to a familiar response from industry that this will reduce available volume and affect financial viability. Hence reducing both harvesting and lumber production would respond to the concerns of these stakeholders and may also convince Canadian environmental and Aboriginal groups not to support USLC complaints. Of course, our forests produce much more than just softwood lumber and proposals to reduce overall harvesting must take into account forest composition, rural development, social demands and other factors. Several provinces have recently revised their forestry regimes, adopting innovative processes for volume allocation and managing forests for multiple values and we propose that other provinces modify their own regimes to promote a broader range of values and uses.

\section{Mandate the Canadian Council of Forest Ministers to coordinate the response}

Canadian provinces have individual needs and priorities, as do companies producing lumber for export, resulting in a variety of responses to US complaints. In comparison, the USLC takes a strong, unified message to the US government, 
and maintains a lobbying presence in Washington even during the periods of agreement. We believe that Canadian diversity has weakened our position in this conflict. Our initial idea, that the federal government impose changes on provinces, was quickly rejected as being both unconstitutional and impractical. Provincial governments and industry associations in each province have the right to develop policy appropriate for their province, but they also have a responsibility to cooperate with other provinces and the federal government in a coordinated response to US complaints. We propose that the Canadian Council of Forest Ministers (CCFM) is an appropriate structure for addressing this problem. The CCFM has a primary mandate of promoting coordination among provinces, can call upon expertise from federal researchers and a variety of departments, and can integrate a variety of stakeholder positions more effectively than could bilateral forums between governments and industry associations. The CCFM is also a permanent structure that will continue after the resolution of Lumber $\mathrm{V}$ and will be able to undertake systematic monitoring of lumber exports and of implementation of the changes that we propose here. Undertaking a more activist role in the lumber dispute would require additional resources for the CCFM, but we are not aware of any other institution that has the legitimacy or ability to coordinate provincial actions.

\section{Implementing our Policy}

There are no magic wands in forest policy, and certainly not in the softwood lumber dispute. Developing a policy, negotiating the details of what should be done, implementing these with agreements, programs, legislation and other tools, evaluating the outcomes and correcting the inevitable mistakes is a long task. This is especially so for the softwood lumber dispute, which has such a long history and where decision-making involves so many actors. We anticipate that implementing the measures we propose above will require twenty yearspossibly longer. We also believe that spending time searching for another quick fix will simply delay our initial steps for a more durable solution. However, foresters, more than any other profession, are equipped to appreciate the need for long-term planning. Implementing our proposal will require three principal phases as illustrated in Fig. 2, coinciding with our expectations for the future of this dispute.

Phase 1 - Lumber V (2016-2021)

The petition lodged by the USLC on November $25^{\text {th }} 2016$ marked the beginning of Lumber V. Looking at the past, Lumber III lasted nearly four years (1991-1994) and Lum- ber IV five years (2001-2006). The USLC is well-prepared for the current conflict (remember that payout of \$500 million) and the new US President has adopted an especially protectionist position. Another five-year conflict seems quite possible, taking us through to 2021 and after the next US presidential election.

Lumber $\mathrm{V}$ is unavoidable and the actions that we propose above are too complex to be implemented while negotiating a new SLA. Therefore, we expect that the next five years will see Canada continuing to defend our regime and producers in international tribunals. Recent changes in timber-pricing systems in some provinces will provide Canada with new arguments, but it seems unlikely that US producers will abandon their complaints. Hence we suggest that Canada use the next five years to start out on the path that we have outlined above. We would like to see the CCFM taking a new role in this conflict, working with provinces to review forestry regimes and timber-pricing systems along with the impacts on lumber exports and prices. Most governments have stated their interest in forest sector innovation and they need to be supported, not only with funding but also by identifying institutional barriers that block new firms and products. These measures may provide some support for negotiations to end Lumber V, but their main value is in preparing provinces and industry for a coordinated effort to introduce our proposed changes during the calm that will (hopefully) be provided by SLA-3.

\section{Phase 2 - The next Softwood Lumber Agreement, SLA-3 [2021-2031]}

We hope that battle fatigue and some Canadian victories will enable SLA-3 to be negotiated and signed in 2021. SLA-1 was for five years and SLA-2 lasted nine years (plus the "coolingoff" year) - we hope for ten years under SLA-3. In the past, Canadian governments and producers have seen the Agreement as a return to stability and a chance to rest and recuperate. We reject this approach and suggest that the duration of SLA-3 be used to embark upon the changes that we have outlined above. Certain provinces are already selling part of their timber through market systems and should have little diffi- 
culty raising this to $55 \%$ (or even higher) by 2030. Other provinces should find it feasible to place this proportion of volume on a market system over ten years. Reducing lumber production and overall harvesting may be achieved in part through pricing mechanisms, but changes in forestry regimes will often be necessary to provide opportunities for creating additional value to offset lower lumber production. Such changes are also necessary to respond to the concerns of Aboriginal peoples, environmentalists and other stakeholders as a step towards removing these sources of conflict as well. Most provinces already have a number of reports and studies with recommendations for updating or for modifying their regimes, but we note that Quebec's new forestry regime took over five years to negotiate and another four years of transition (Gagné and Jasmin 2010, Amedzro St-Hilaire and Chiasson 2012). Timber pricing, volume allocation and regime modification must all be left to individual provinces, but the CCFM can usefully facilitate the exchange of information about how different systems work in provinces, and in ensuring that all provinces are progressing. Expanding innovation, value-adding and diversifying forest products will require a range of measures including roles for agencies such as FPInnovation and universities, but also regime change to make fibre and other forest resources available for entrepreneurs who seek to market new products. Finally, in anticipation of the end of SLA-3 and of a subsequent Lumber VI, Canadian producers and governments may be advised to establish a financial "war chest". Implementation of our proposals will incur costs on industry and require financial support by government, but it will obviously be essential to avoid providing US producers with evidence of Canadian subsidies.

Monitoring and evaluation of policy implementation is a key part of the Mayers and Bass (1999) policy model but seems to have been relatively absent in past cycles of this dispute. SLA-2 (articles 13 and 15) provided for mutual reporting on volumes and prices and for the establishment of a joint US-Canada committee and a working group. While we assume that this was done by the federal government, we were not able to find information, data or reports that provided a thorough analysis of the implementation of SLA-2. As noted above, we propose that the CCFM be mandated to coordinate Canada's response, and especially that it monitor implementation measures and outcomes across the country. This would require much more than recording volumes and prices (as called for in SLA-2) - we would expect the CCFM to monitor the transition to market price systems, the modification of forestry regimes, changes in lumber production and harvesting, and the expansion of value-added transformation and product diversification. An important advantage here would be the sharing of experience, lessons and effectiveness of various measures as they are applied in different provinces. We believe that it is essential that Canada use the period of calm during SLA-3 not to rest and recuperate but rather to prepare for Lumber VI.

\section{Phase 3 - Lumber VI (2031-2035)}

Despite any and all changes that Canadian governments and producers make between now and the end of SLA-3, we expect that US producers will launch another complaint shortly after its end. After all, why abandon a proven strategy? In order to defend itself against these complaints, Canada will need to demonstrate the changes it has made and the effects of these upon timber pricing and volume. Comparisons of prices from private forests and from traditional and marketprice systems on public forests across the country will be needed, along with reliable data on US production and pricing and the impact of SLA-3 on US consumers. In all likelihood, Canada will again have to defend itself in investigations by the US government (which will be subject to lobbying by the USLC), and subsequently through appeals in accordance with NAFTA, the World Trade Organisation, the GATT and whatever other international agreements are in place in the 2030s. Nevertheless, if Canada undertakes coordinated action over the next fifteen years to prepare itself, we are hopeful that by 2035 we will be able to win Lumber VI and softwood lumber will be become just another product traded between Canada and the USA under the provisions of NAFTA (or its successor). However, if Canada does not win Lumber VI, then we will probably be condemned to another cycle of agreement and conflict, and some of us will retire without seeing a conclusion to this dispute.

\section{Conclusion}

As forestry students, we recognise that we lack experience and expertise in international commerce of timber products and indeed, in policy analysis. We conclude this text, knowing that the USLC has filed a new complaint and we cannot help but see how much the beginning of Lumber $\mathrm{V}$ resembles previous versions of the dispute-the US says that Canadian governments subsidize timber production; we say that we don't and we risk spending the next five years paying duties before arriving at an agreement that limits the volume that we export to the USA. As future foresters, we would like to avoid having this issue dominating our industry for the length of our careers. We believe that there is a need to break out of the box which appears to define the softwood lumber dispute. Our suggestions here are certainly not perfect, but we feel that they provide some options for moving forward to a long-term resolution of this dispute. We hope that professionals and representatives of the many Canadian actors involved in this issue will be able to use this analysis as a starting point for negotiations and for a strategy that takes into account the needs and preferences of each. This conflict has had an impact in the careers of forestry students for more than a generation. We hope to see this issue resolved during our careers and that forestry students in 2030 or 2050 will be able to work on moving forestry forward, rather than ruminating on an old dispute.

\section{Acknowledgements}

We thank Michel Vincent of the Quebec Forest industry Council for sharing his encyclopedic knowledge of this issue with us.

\section{References}

Amedzro St-Hilaire, W. and G. Chiasson. 2012. État et gouvernance des forêts au Québec. Revue française d'administration publique 142 (517-532.

Cashore, B.W. 1997. Flights of the Phoenix: Explaining the durability of the Canada-U.S. softwood lumber dispute. Canadian-American Center, University of Maine, Orono, ME. 
Descôteaux, D. and P. Martin. 2009. Désunis dans l'adversité: Les consommateurs américains et le conflit du bois d'œuvre entre le Canada et les États-Unis. Études internationales 40(3): 373-394.

Ellefson, P.V. 1992. Forest Resources Policy : Process, Participants and Programs. McGraw-Hill, New York.

Gagné, G. and É. Jasmin. 2010. Les politiques forestières du Québec et le commerce « loyal »: Le différend sur le bois d’ouvre. Can. Public Pol. 36(1): 91-106.

Gagné, G. and M. Paulin. 2013. The Softwood Lumber Dispute and US Allegations of Improper NAFTA Panel Review. Am. Rev. Can. Studies 43(3): 413-423.

Mayers, J. and S. Bass. 1999. Policy That Works for Forests and People: Executive Summary of Series Overview. International Institute for Environment and Development. Policy that Works for Forests and People Series. London.

Parajuli, R. and D. Zhang. 2016. Welfare impacts of the 2006 United States - Canada Softwood Lumber Agreement. Can. J. Forest. Res. 46(7): 950-958.
RNCanada. 2016. Létat des forêts au Canada: Rapport annuel 2015. Ottawa. 75 p.

Siry, J.P., K. McGinley, F.W. Cubbage and P. Bettinger. 2015. Forest Tenure and Sustainable Forest Management. Open J. Forest. 5: 526-545.

Zhang, D. 2007. The Softwood Lumber War: Politics, Economics, and the Long U.S.-Canadian Trade Dispute. Resources for the Future, Washington, DC.

Zhang, D. and D. Laband. 2005. From Senators to the President: Solve the lumber problem or else. Public Choice 123(3): 393-410.

Ziedi, R., N. Lehoux and L. Lebel 2014. Système d’enchères pour l'approvisionnement forestier : Une revue des façons de faire dans le monde. In: MOSIM 2014, 10ème Conférence Francophone de Modélisation, Optimisation et Simulation, Nancy, France. 